УДК 330

\title{
ВЗАИМОСВЯЗЬ ВИДОВОГО СОСТАВА КОЖНОЙ МИКРОФЛОРЫ И ВЫБОРА НАРУЖНОЙ ТЕРАПИИ У ПАЦИЕНТОВ С АЛЛЕРГОДЕРМАТОЗАМИ
}

\author{
Тишина Екатерина Игоревна \\ к.М.н., доцент \\ Хелена Коэльо Ода \\ студент
}

Научный руководитель: Силина Лариса Вячеславовна д.м.н., профессор ФГБОУ ВО «Курский государственный медицинский университет»

\begin{abstract}
Аннотация: Микробиота кожи - это динамически меняющаяся структура, которая требует более детального анализа и изучения у разных групп пациентов, а также дифференциации и классификации для дальнейшего изучения. Изучение вопроса о микробиоте кожи человека является важным и значимым в связи с тем, что микробиота кожи является одним из патогенетических звеньев дерматологических заболеваний и может существенно влиять на течение и исход заболевания.
\end{abstract}

Ключевые слова: микробиота, атопический дерматит, глюкокортикостероиды, наружная терапия, вторичная пиодермия.

\section{THE CORRELATION BETWEEN THE SPECIES' CONTENT OF CUTANEOUS MICROFLORA AND THE CHOICE OF EXTERNAL PHARMACOTHERAPY IN PATIENTS WITH ALLERGIC DERMATOSES}

\section{Tishina Ekaterina Igorevna Helena Coelho Oda Silina Larisa Vyacheslavovna}

\footnotetext{
Abstract: Human's microbiota is viewed as an independent, complicated and dynamically changing organ, regulating plenty of metabolic processes of our organism.
} 
Research and analysis of skin microbiota is topical and important as it forms the pathogenesis of dermatological diseases and may significantly influence the course and the outcome of a disease.

Key words: microbiota, atopic dermatitis, glucocorticosteroids, external therapy, secondary pyoderma.

The human organism works in homeostasis to maintain the balance according to the conditions necessary for survival. Certain evolutionary formed mechanisms influence this stability greatly, and one of them is the microbiota. It's a complex of microorganisms, which symbiotically co-exist with the host's microorganism. Microbiota of the skin, oral mucosa and the gut is distinguished; it has a different content and characteristics, depending on a localization.

Human's microbiota has been consequently studied, starting with the founders of microbiology, great scientists, Louis Pasteur and Robert Koch. Later on, the development of genomics broadened significantly the spectrum of opportunities for the human's microbiota research. It has put a basis to the investigation of the microbiota's genome - microbiome. Totally the microbiome includes approximately 3000000 genes, in comparison with the human's genome, which numbers 23000 genes.

Each person has its own microbiome, determined by plenty of factors, such as diet, lifestyle, hormones, genetics and environment. Some factors that are known to influence the skin microbiota are skin $\mathrm{pH}$, moisture, temperature, sun exposure, oxygen, innate host defenses, interactions with the other microorganisms, hygiene, etc.

The skin microbiota is classified into the resident microbiota and the transient microbiota. The resident microbiota is composed of the microorganisms which are constantly present on a skin surface and cannot be removed. They are found in the epidermis, hair follicles, sebaceous and sweat glands. Within the skin, this microbiota is found in the epidermal and dermal layers. The resident microbiota is made up mostly by Staphylococcus, Micrococcus, Corynebacterium, Brevibacterium, Dermabacter, and Malasezzia, but it has an enormous diversity of species that differ according to the areas of the body and in each person. This type of microbiota has an important role in human health, because it protects the skin against pathogenic microorganisms. 
On the other hand, the transient microbiota consists of microorganisms that are temporarily present on the skin and usually includes gram positive bacteria, E.coli, Klebsiella spp., Pseudomonas spp,, Salmonella spp., S. aureus, C. albicans, viruses, and others. This kind of microbiota may include pathogenic microorganisms.

Besides the classification of resident and transient, the microorganisms present in our microbiota can be divided according to the relationships towards our organism. They can be: commensals, which are the organisms that reside on the skin and acquire a positive benefit from us, but for us they are neutral; or symbionts, when both the micro- and macroorganism acquire the benefit; or pathogens, when only the microorganisms receive the benefit, but cause harm to the human's organism [1].

A wide range of dermatoses, especially with a chronic recurrent course is associated with the microbiota's disbalance. The pathogenic theories claim that due to an individual, mainly genetically predisposed reactions to combinations of metabolic, endocrine disorders, toxico-infectious and neurogenic trigger mechanisms, the organism fails to maintain homeostasis, including the normal regulation of cutaneous microbiota. Thus, the representatives of the commensal flora may acquire the pathogenic features. Also, chronic inflammation of the skins results in imperfect barrier function, which enables the transient pathogenic species to penetrate into the skin and persist, supporting the sensitization and inflammation.

That is all actual for atopic dermatitis. Within the structure of dermatological diseases the rate of atopic dermatitis reaches up to $10-12 \%$. The disease is spread worldwide, predominantly among the urban population. As a rule manifestation period is during the first years of life, according to statistics data may affect up to $20 \%$ of children and $10 \%$ of adult population of the developed countries [2]. The rate of the disease has increased significantly during the last 30 years and continues to grow.

It is a chronic recurrent skin disease with age periodization correlating with the morphology of the foci of inflammation. Intense pruritus is present, which refers to another name of the disease - neurodermatitis. The etiology and pathogenesis is of a multifactorial nature and involves a series of different causes, from skin barrier dysfunction to immune response, and environmental factors [3]. The disbalance of the T-lymphocytes' chain as well as the high levels of immunoglobulin $\mathrm{E}$ was given as the main pathogenic mechanism of atopic dermatitis, but the recent studies have 
showed that besides immunological, the inherited disturbance of the protein filaggrin metabolism makes a great contribution to the development of the disease [4].

The horny layer of the epidermis, or stratum corneum, is composed of flattened corneocytes and extracellular lipid matrix [5]. The corneocytes present in this epidermal layer have keratin filaments with filaggrin and profilaggrin in its interior, these proteins are important because they act on the cytoregulation making the horny layer compact by attaching the corneocytes to one another, this action makes this layer resistant to the loss of water as well as to possible transient pathogens or aggressive pathogens in the skin, it performs the protective function [6, 49:1-7].

Patients with low levels or no filaggrin have a favorable background for the development of atopic dermatitis. Because of the inability of the epidermis to provide a barrier function and to prevent transepidermal water loss, the skin layers become a convenient target for dysbalanced micribiota.

The relevance and purpose of the research. To further understand the relationship between the microbiota's species and the different ways of treatment in patients with atopic dermatitis. How the disbalance, or increase in certain types of species may lead to changes in the treatment of individual patients.

The materials and methods. Laboratory diagnostic results of cultural skin investigation have been analyzed in 112 patients with atopic dermatitis, complicated by 2 ry pyoderma. The course of atopic dermatitis was: mild in 5 patients $(4,5 \pm 1,9 \%)$, moderate $-48(42,9 \pm 4,7 \%)$, severe $-59(52,6 \pm 4,9 \%)$.

Control group included 55 healthy individuals ( 32 females, 23 males).

Research values.

Table 1

112 patients with atopic dermatitis complicated by secondary pyoderma distributed according to age and sex

\begin{tabular}{|c|c|c|c|c|c|c|c|c|}
\hline \multirow{2}{*}{$\begin{array}{c}\text { Age, } \\
\text { Years }\end{array}$} & \multicolumn{2}{|c|}{$18-25$} & \multicolumn{2}{|c|}{$26-50$} & \multicolumn{2}{c|}{$51-70$} & \multicolumn{2}{c|}{ Total } \\
\cline { 2 - 9 } & Abs. & $\%$ & Abs. & $\%$ & Abs. & $\%$ & Abs. & $\%$ \\
\hline $\begin{array}{c}\text { Females } \\
(\mathrm{n}=76)\end{array}$ & 33 & $43,4 \pm 5,7$ & 32 & $42,1 \pm 5,6$ & 11 & $14,5 \pm 4,1$ & 76 & $67,9 \pm 4,4$ \\
\hline $\begin{array}{c}\text { Males } \\
(\mathrm{n}=36)\end{array}$ & 13 & $36,1 \pm 8,0$ & 16 & $44,4 \pm 8,3$ & 7 & $19,4 \pm 6,5$ & 36 & $32,1 \pm 4,7$ \\
\hline Total & 46 & $41,1 \pm 4,6$ & 48 & $42,9 \pm 4,7$ & 18 & $16,1 \pm 3,5$ & 112 & 100 \\
\hline
\end{tabular}


Table 2

The results of bacteriological investigation of the 112 patients with atopic dermatitis complicated by secondary pyoderma (Abs/\%)

\begin{tabular}{|c|c|c|}
\hline S. aureus & 98 & $87,5 \pm 3,1$ \\
\hline S. epidermidis & 87 & $77,6 \pm 3,9$ \\
\hline S. haemolyticus & 69 & $61,6 \pm 4,6$ \\
\hline S. saprophyticus & 56 & $50,0 \pm 4,7$ \\
\hline S. pneumoniae & 43 & $38,4 \pm 4,6$ \\
\hline Streptococcus pyogenes & 30 & $26,8 \pm 4,2$ \\
\hline St.faecalis & 12 & $10,7 \pm 3,1$ \\
\hline Enterococcus faecalis et faecium & 9 & $8,0 \pm 2,6$ \\
\hline Pseudomonas aeruginosa & 11 & $9,8 \pm 2,8$ \\
\hline Klebsiella pneumoniae & 5 & $4,5 \pm 2,0$ \\
\hline Esherichia coli & 5 & $4,5 \pm 2,0$ \\
\hline Enterobacter cloacae & 6 & $5,4 \pm 2,2$ \\
\hline Enterobacter aerogenes & 3 & $2,7 \pm 1,8$ \\
\hline Proteus vulgaris & 9 & $8,0 \pm 2,6$ \\
\hline Proteus miabilis & 11 & $9,8 \pm 2,8$ \\
\hline
\end{tabular}

According to the results of the research, it is possible to see (Table 1) that there is a predominant rate in females aged between 18 and 25 years old $(43,4 \pm 5,7 \%)$. For males the predominant rate is between 26 and 50 years old $(44,4 \pm 8,3 \%)$. On the total amount between both genders, patients between 26 to 50 years old, have a predominance in atopic dermatitis complicated by secondary pyoderma $(42,9 \pm 4,7 \%)$.

As reported by the bacteriological investigation (Table 2), Staphylococcus aureus is the microorganisms most likely to be found and was detected on the skin of $98(87,5 \pm 3,1 \%)$ patients. This microorganism is known to be the transient flora.

The growth of the fungal flora has been detected in $28(25 \pm 4,1 \%)$ patients. The species' content was represented by: yeast fungi $(32,1 \%)$, dermatophytes $(33,5 \%)$, mold fungi $(22,4 \%)$, associations $(12 \%)$.

The rate of the patients with non-staphylococcal bacterial flora and its associations with fungi was $18 \%$.

The external treatment of atopic dermatitis is with the use of topical glucocorticosteroids or calcineurin inhibitors. These medicaments bring a positive effect to the patient suppressing the inflammation by decreasing the release of mediators and reducing subjective and objective clinical symptoms (itchiness, erythema and exudation). However, glucocorticosteroids and calcineurin inhibitors 
administration should be very rational in atopic patients, because of the high risk to cause and/or to increase the secondary infection, due to dysbalance of the microbiota in such patients. Monocomponent antibacterial or antifungal creams or ointments may either cause exacerbation of atopic dermatitis.

Methods of choice for the external therapy in atopic dermatitis, complicated by 2ry infection are the composite creams/ointments, such as Bethamethasone valerate $0,001 \%+$ Fusidic acid $0,02 \%$ or the tricomponent therapy which is Gentamicin $0.05 \%$ + Bethamethasone dipropionate $0.1 \%$ + Clotrimazole $1 \%$.

Gentamicin is an antibacterial medicine, active against: Proteus spp., Escherichia coli, Klebsiella spp., Salmonella spp., Shigella spp., Campylobacter spp., Staphylococcus spp., Enterococcus faecalis, Serratia spp., Pseudomonas spp., Acinetobacter spp., Citrobacter spp.

Clotrimazole is effective against: dermatophytes (Trichophyton rubrum, Trichophyton mentagrophytes, Epidermophyton floccosum, Microsporum canis), yeast and mold fungi (Candida spp., Torulopsis glabrata, Rhodotorula spp., Pityrosporum orbiculare).

Fusidic acid is a bacteriostatic agent, active against: Staphylococcus, Streptococcus, Corynebacterium. The importance of the clinical use of fusidic acid is connected with its' activity against methicillin-resistant Staphylococcus aureus.

Conclusion: human's microbiota is viewed as an independent, complicated and dynamically changing organ, regulating plenty of metabolic processes of our organism.

Research and analysis of skin $\mathrm{m}$ icrobiota is topical and important as it forms the pathogenesis of dermatological diseases and may significantly influence the course and the outcome of a disease.

\section{References}

1. Microbial Relationships. Biology LibreTexts, Sep 8, 2020. Available in: https://bio.libretexts.org/Courses/Manchester_Community_College_(MCC)/Remix _ of_Openstax\%3AMicrobiology_by_Parker_Schneegurt_et_al/08\%3A_Microbial_G rowth/8.05\%3A_Other_Environmental_Conditions_that_Affect_Growth.

2. David Boothe W, Tarbox JA, Tarbox MB. Atopic Dermatitis: Pathophysiology. Adv Exp Med Biol. 2017;1027:21-37. doi: 10.1007/978-3-31964804-0_3. PMID: 29063428. Available in: https://pubmed.ncbi.nlm.nih.gov/ 29063428/. 
3. Atopic dermatitis (eczema). Mayo clinic. Available in: https://www.mayoclinic.org/diseases-conditions/atopic-dermatitis-eczema/ symptoms-causes/syc-20353273.

4. FGL gene. MedlinePlus. Available in: https://medlineplus.gov/genetics/ gene/flg/.

5. MURPHREY B. Morgan; MIAO, H. Julia; ZITO, M. Patrick. Histology, Stratum Corneum, StatPearls Publishing, 2021 Jan. Available in: https://www.ncbi.nlm.nih.gov/books/NBK513299/.

6. KEZIC S.; JAKASA I. Filaggrin and Skin Barrier Function, Pubmed, 2016, 49: 1-7. Available in: https://pubmed.ncbi.nlm.nih.gov/26844893/. 